\title{
First Report of Cannibalism in the Saba Anole (Anolis sabanus), with a Review of Cannibalism in West Indian Anoles
}

\author{
Robert Powell ${ }^{1}$ and Adam Watkins ${ }^{2}$ \\ 11Department of Biology, Avila University, Kansas City, Missouri 64145, USA (robert.powell@avila.edu) \\ ${ }^{2}$ Chizzilala Video Productions, Saba (adam@chizzilala.com)
}

A $\mathrm{t}$ midday on 17 October 2014 at the Ecolodge on Saba $\left(17^{\circ} 37^{\prime} 47^{\prime \prime} \mathrm{N}, 63^{\circ} 13^{\prime} 52^{\prime \prime} \mathrm{W}\right.$; elev. $\left.397 \mathrm{~m}\right)$, we observed an adult male Saba Anole (Anolis sabanus) with a conspecific juvenile in its mouth (Fig. 1). When first seen, the juvenile was still alive, but it showed no signs of life as the adult carried it away after being disturbed by our presence. We did not observe ingestion. This is the first report of cannibalism in this species. Cannibalism is not uncommon in West Indian anoles (Gerber 1999, Henderson and Powell 2009), with 18 (now 19) species known to eat conspecifics (Table 1).

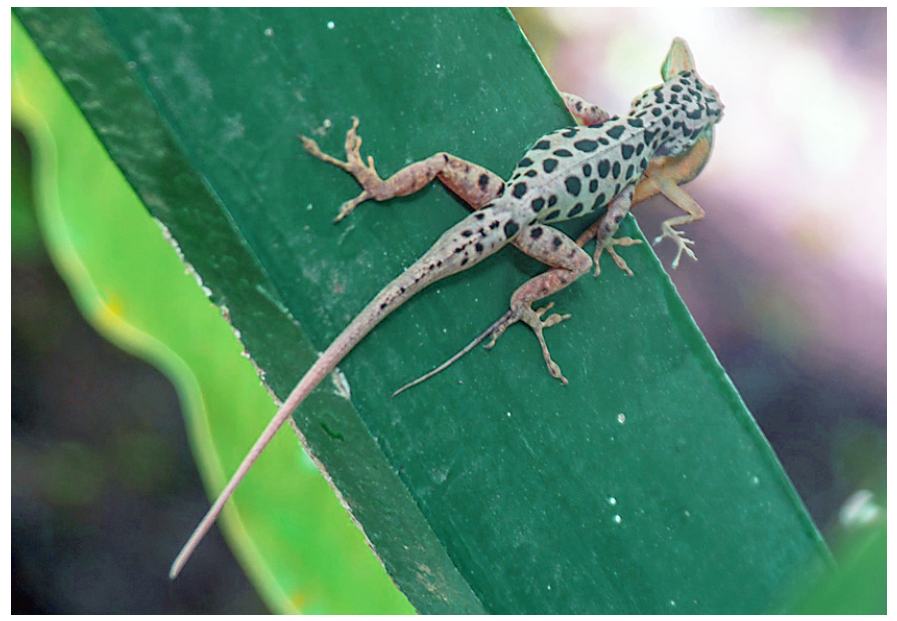

Fig. 1. Adult male Saba Anole (Anolis sabanus) preying on a conspecific juvenile. Photograph by Adam Watkins.

\section{Literature Cited}

Bowersox, S.R., S. Calderón, G. Cisper, R.S. Garcia, C. Huntington, A. Lathrop, L. Lenart, J.S. Parmerlee, Jr., R. Powell, A. Queral, D.D. Smith, S.P. Sowell, and K.C. Zippel. 1994. Miscellaneous natural history notes on amphibians and reptiles from the Dominican Republic. Bulletin of the Chicago Herpetological Society 29:54-55.

Breuil, M. 2002. Histoire naturelle des amphibiens et reptiles terrestres de l'Archipel Guadeloupéen. Guadeloupe, Saint-Martin, Saint-Barthélemy. Patrimoines Naturels, Paris 54:1-339.
Carr, D.K., R. Powell, and J.S. Parmerlee, Jr. 1989. Anolis whitemani whitemani. Food habits. Herpetological Review 20:49-53.

Cochran, P.A. 1989. Anolis sagrei (Brown Anole). Behavior. Herpetological Review 20:70. Fitch, H.S. 2003. Dewlaps and the lack thereof: Or, lizard studies in the Neotropics, pp. 153-157. In: R.W. Henderson and R. Powell (eds.), Islands and the Sea: Essays on Herpetological Exploration in the West Indies. Contributions to Herpetology, vol. 20. Society for the Study of Amphibians and Reptiles, Ithaca, New York.

Fitch, H.S. and R.W. Henderson. 1987. Ecological and ethological parameters in Anolis bahorucoensis, a species having rudimentary development of the dewlap. Amphibia-Reptilia 8:69-80.

Fitch, H.S., R.W. Henderson, and H. Guarisco. 1989. Aspects of the ecology of an introduced anole: Anolis cristatellus in the Dominican Republic. AmphibiaReptilia 10:307-320.

Fläschendräger, A. and L.C.M. Wijffels. 1996. Anolis. Natur und Tier, Münster, Germany.

Fläschendräger, A. and L.C.M. Wijffels. 2009. Anolis. 2. vollständig überarbeitete und erweitere Auflage. Natur und Tier, Münster, Germany.

Gerber, G.P. 1999. A review of intraguild predation and cannibalism in Anolis, pp. 28-39. In: J.B. Losos and M. Leal (eds.), Anolis Newsletter V. Washington University, St. Louis, Missouri.

Gerber, G.P. and A.C. Echternacht. 2000. Evidence for asymmetrical intraguild predation between native and introduced Anolis lizards. Oecologia 124:599-607.

Henderson, R.W. and R. Powell. 2009. Natural History of West Indian Reptiles and Amphibians. University Press of Florida, Gainesville.

Hicks, R.A. and R.L. Trivers. 1983. The social behavior of Anolis valencienni, pp. 570-595. In: A.G.J. Rhodin and K. Miyata (eds.), Advances in Herpetology and Evolutionary Biology: Essays in Honor of Ernest E. Williams. Museum of Comparative Zoology, Harvard University, Cambridge, Massachusetts.

Holanova, V. and J. Hribal. 2004. Dos anolis cubanos: Anolis bartschi y Anolis lucius. Reptilia (Spain) 47:62-68.

Lister, B.C. 1976. The nature of niche expansion in West Indian Anolis lizards. I. Ecological consequences of reduced competition. Evolution 30:659-676.

MacLean, W.P. 1982. Reptiles and Amphibians of the Virgin Islands. MacMillan Caribbean, London.

Martínez Reyes, M. and L. Rodríguez Schettino. 1987. Canibalismo en Leiocephalus carinatus (Gray) (Sauria: Iguanidae). Miscelanea Zoológica 29:1-2.

Powell, R., R.W. Henderson, and J.S. Parmerlee, Jr. 2005. Reptiles and Amphibians of the Dutch Caribbean: St. Eustatius, Saba, and St. Maarten. St. Eustatius National Parks Foundation, Gallows Bay, St. Eustatius, Netherlands Antilles.

Rand, A.S. 1967. Ecology and social organization in the iguanid lizard Anolis lineatopus. Proceedings of the United States National Museum 122:1-79.

Rodríguez Schettino, L. 1999a. Introduction, pp. 1-16. In: L. Rodríguez Schettino (ed.), The Iguanid Lizards of Cuba. University Press of Florida, Gainesville.

Rodríguez Schettino, L. 1999b. Systematic accounts of the species, pp. 104-380. 
Table 1. Records of cannibalism by West Indian anoles (Anolis).

\begin{tabular}{|c|c|}
\hline Species and island(s) & References \\
\hline A. aeneus (Grenada) & Stamps 1983 \\
\hline A. bartschi (Cuba) & Holanova and Hribal 2004 \\
\hline A. chlorocyanus (Hispaniola) & Bowersox et al. 1994 \\
\hline A. conspersus (Grand Cayman) & Schoener 1967, Gerber and Echternacht 2000 \\
\hline A. cybotes (Hispaniola) & Fitch and Henderson 1987, Fitch 2003 \\
\hline A. evermanni (Puerto Rico) & Wolcott 1923; Schmidt 1920, 1928 \\
\hline A. homolechis (Cuba) & Rodríguez Schettino 1999b \\
\hline A. imias (Cuba) & $\begin{array}{l}\text { Rodríguez in Martínez Reyes and Rodríguez Schettino 1987, González Bermudez } \\
\text { in Rodríguez Schettino 1999a }\end{array}$ \\
\hline A. marmoratus (Guadeloupe) & Breuil 2002 \\
\hline A. porcatus (Cuba) & Alayón García in Socarrás et al. 1988 \\
\hline A. roquet (Martinique) & Schoener and Gorman 1968 \\
\hline A. sabanus (Saba) & this report \\
\hline A. sagrei (Cuba, Grand Cayman) & Lister 1976, Cochran 1989, Gerber and Echternacht 2000 \\
\hline A. valencienni (Jamaica) & Hicks and Trivers 1983 \\
\hline A. whitemani (Hispaniola) & Carr et al. 1989 \\
\hline
\end{tabular}

In: L. Rodríguez Schettino (ed.), The Iguanid Lizards of Cuba. University Press of Florida, Gainesville.

Rodríguez Schettino, L and M. Martínez Reyes. 1994. Características tróficas de una población de Anolis lucius (Iguania: Polychridae) en la costa septentrional de Cuba. Avicennia 1:67-77.

Schmidt, K.P. 1920. Contribution to the herpetology of Porto Rico. Annals of the New York Academy of Sciences 28:167-200.

Schmidt, K.P. 1928. Amphibians and reptiles of Porto Rico, with a list of those reported from the Virgin Islands. New York Academy of Sciences 10, Part $1: 1-160+$ plates I-IV.
Schoener, T.W. 1967. The ecological significance of sexual size dimorphism in size in the lizard Anolis conspersus. Science 155:474-477.

Socarrás, A.A., J. de la Cruz, G. Garcés G., and A. Ruiz. 1988. Saurofagia en Anolis (Sauria: Iguanidae). Miscelanea Zoológica 38:4.

Stamps, J.A. 1983. The relationship between ontogenetic habitat shifts, competition and predator avoidance in a juvenile lizard (Anolis aeneus). Behavioral Ecology and Sociobiology 12:19-33.

Wolcott, G.N. 1923. The food of Porto Rican lizards. Journal of the Department of Agriculture of Porto Rico 7:5-38. 